\title{
Physical Activity, Exercise, and Physical Rehabilitation
}

\author{
Camila Astolphi Lima, Renato Barbosa dos Santos, \\ and Monica Rodrigues Perracini
}

\begin{abstract}
Enhancing physical activity promotes positive health trajectories throughout the life course. Physical activity should be tailored and graded to suit older adults' capacities and needs and can be combined with rehabilitation interventions to manage geriatric syndromes and disability. This chapter provides a summary of current evidence about the role of physical activity for older adults, emphasizing nutritional aspects. We also present strategies to help health-care professionals to enhance physical activity participation.
\end{abstract}

\section{Keywords}

Physical activity $\cdot$ Exercise $\cdot$ Nutrition $\cdot$ Rehabilitation $\cdot$ Older adults

This chapter is a component of Part II: Special Topic in Geriatric Nutrition.

For an explanation of the grouping of chapters in this book, please see Chap. 1: "Overview of Nutrition Care in Geriatrics and Orthogeriatrics."

C. A. Lima $\cdot$ R. B. dos Santos

Master's and Doctoral Programs in Physical Therapy, Universidade Cidade de São Paulo, São Paulo, SP, Brazil

M. R. Perracini $(\bowtie)$

Master's and Doctoral Programs in Physical Therapy, Universidade Cidade de São Paulo, São Paulo, SP, Brazil

Master's and Doctoral Programs in Gerontology, Faculty of Medical Sciences, Universidade Estadual de Campinas, São Paulo, SP, Brazil

e-mail: monica.perracini@unicid.edu.br

Ó. G. Geirsdóttir, J. J. Bell (eds.), Interdisciplinary Nutritional Management and 


\section{Learning Outcomes}

By the end of this chapter, you will be able to:

- Apply the updated recommendations of physical activity for older people.

- Justify health benefits of physical activity in older adults.

- Describe the rationale for combined exercise and nutritional interventions.

- Report strategies to enhance physical activity level.

\subsection{Importance of Physical Activity in Older Adults}

Healthy aging conceptualization is grounded in fostering the functional ability of older people, so they can be and do what they value [1]. Being physically active is a key factor to prevent and maintain intrinsic capacity and to optimize functional ability in old age. Physical activity (PA) is considered as any bodily movement produced by the contraction of muscles, increasing energy expenditure [2]. In a new and broader definition, PA involves people moving, acting, and performing within culturally specific spaces and contexts and is influenced by a unique array of interests, emotions, ideas, instructions, and relationships [3]. Exercise is defined as planned, structured, and repetitive movement to improve or maintain some component of physical fitness [2].

PA can be undertaken as part of recreation and work or as part of domestic tasks. While some PA activities can be more pleasant than others, with associated mental and social benefits, if older people undertake PA regularly and in a sufficient duration and intensity, they will have health benefits [4]. Reducing physical inactivity is part of World Health Organization (WHO) global strategy to manage noncommunicable diseases (NCDs). Implementing community-wide public education and awareness for PA and providing PA counseling and referral as part of routine primary health-care services are considered "best buys" interventions, particularly for low- and middle-income countries [5].

\subsection{Recommendations for Physical Activity}

Recommendations suggest 150-300 min of moderate-intensity aerobic physical activity or at least 75-150 min of vigorous-intensity aerobic physical activity or an equivalent combination of moderate- and vigorous-intensity activity throughout the week, for substantial health benefits [6]. Aerobic activity is recommended to be performed in bouts of at least 10 min each. There is high evidence of an inverse dose response relationship between volume of aerobic physical activity and risk of physical functional limitations in the general older adult population.

For older adults that are not able to complete the above recommendations, they should be physically active as their abilities and conditions allow [6]. As highlighted in the 2020 WHO recommendation, "Doing some physical activity is better than doing none." 
Older adults should include multicomponent physical activity that combines aerobic, strengthening, and functional balance on 3 or more days a week; strength training for all major muscle groups should be considered 2 or more days a week [6]. For adults with chronic conditions, a frequency of 3 days a week is commonly recommended.

The types of PA most popular for older adults are light intensity, such as walking and gardening [2]. Older adults should gradually increase the duration and frequency of moderate-intensity activity rather than rapidly increasing to vigorousintensity activity $[6,7]$. Growing evidence supports that light-intensity activities, like a slow walking or housework (e.g., ironing and dusting), also offer a protective benefit against diseases and disability [8, 9]. Older adults should be as active as possible. Even when recommendations are not met, efforts to integrate more lightintensity activities into everyday life are beneficial.

\subsection{Benefits of Physical Activity}

Márcia has worked on a cattle ranch for most of her life. Although she was thin, she was a strong, hardworking, healthy, and happy woman who slept well at night. She did not take any medications and, although having annual checkups with the community nurse, had never needed to see the doctor or go to hospital.

Benefits of PA in middle age to older adult years include the maintenance of balance, strength, flexibility, and exercise capacity (Table 14.1). Whether achieved through prescribed multimodal or multicomponent exercises or mustering cattle and rural fencing, PA optimizes physical, mental, and musculoskeletal health, healthrelated quality of life, and functional independence and abilities and decreases the risk of falling.

Following a fall off her horse at the age of 76, Márcia spent most of her days in bed. She had poor dietary intake, ongoing falls, and urinary incontinence over the next 6 months. Márcia's son José eventually convinced her to receive a visit from the local community nurse. Shortly afterward, Márcia presented to hospital where multiple vertebral crush fractures, malnutrition, frailty, vitamin D deficiency, osteoporosis, and depression were diagnosed.

Older adults presenting with geriatric syndromes, such as falls and fragility fractures, malnutrition, frailty, depression, and urinary incontinence, may present with different levels of functional disability and deconditioning, resulting in low physical 
Table 14.1 Benefits of physical activity in older adults

\begin{tabular}{|c|c|}
\hline Potential benefit & Examples \\
\hline $\begin{array}{l}\text { Health conditions and } \\
\text { mortality }\end{array}$ & $\begin{array}{l}-22 \% \downarrow \text { all-cause mortality }[10] \\
-12 \% \downarrow \text { risk of breast cancer }[11] \\
\text { - Noncommunicable disease (e.g., coronary heart disease, type } \\
2 \text { diabetes) prevention/management }[2,12]\end{array}$ \\
\hline $\begin{array}{l}\text { Cognitive function, mental } \\
\text { health, and health-related } \\
\text { quality of life }\end{array}$ & $\begin{array}{l}-36 \% \downarrow \text { risk of cognitive decline }[13,14] \\
-24 \% \downarrow \text { all-cause dementia (moderate-intensity) } \\
-28 \% \downarrow \text { all-cause dementia (high-intensity) }[13,14] \\
\text { - } 40 \% \downarrow \text { Alzheimer's disease development }[11] \\
-21 \% \downarrow \text { incident depression (high-intensity) [11] } \\
\text { - Poor sleep quality and declining intrinsic capacity } \\
\text { - Increased health-related quality of life }\end{array}$ \\
\hline Musculoskeletal health & $\begin{array}{l}\text { - } 31 \% \downarrow \text { in relative risk of fracture (hip, wrist, and vertebral } \\
\text { fractures) [15] } \\
\text { - Improved lumbar spine bone mineral density,may improve } \\
\text { hip (femoral neck) bone mineral density [15] } \\
\text { - Probable positive impact on frailty and sarcopenia (resistance } \\
\text { training, combination of resistance, balance, endurance, and } \\
\text { function exercise) [16] }\end{array}$ \\
\hline $\begin{array}{l}\text { Physical function and } \\
\text { disability }\end{array}$ & $\begin{array}{l}\text { - Approximately } 50 \% \text { likely } \downarrow \text { risk of functional limitations/ } \\
\text { disability (moderate/high levels) [17] } \\
\text { - Strongly recommended to } \downarrow \text { loss of physical function and } \\
\text { mobility (multimodal or multicomponent exercises including } \\
\text { balance, strength, flexibility, and functional training) [17] } \\
\text { - Delayed disability or functional limitation and prolonged } \\
\text { disability-free life (high levels in middle age) [18] }\end{array}$ \\
\hline Fall prevention & $\begin{array}{l}-31 \% \downarrow \text { in falls (dance-based mind-motor activities [19] } \\
\text { - } 23 \% \downarrow \text { in falls (structured exercise) [20] } \\
\text { - } 42 \% \text { estimated reduction in the rate of falls (exercise dose of } \\
\text { more than } 3 \mathrm{~h} / \text { week of balance and functional exercises) [20] } \\
\text { - Exercise as a single intervention did not reduce falls but was } \\
\text { able to enhance mobility in frail older people recently } \\
\text { discharged from hospital [21] }\end{array}$ \\
\hline
\end{tabular}

activity levels and the adoption of sedentary behavior over time. Appropriately prescribed exercise and PA are demonstrated to be safe and have a beneficial effect on functional ability; these benefits can be extended to older adults like Márcia, even in the presence of existing physical and functional limitations. Multimodal or multicomponent exercises including balance, strength, flexibility, and functional training are strongly recommended to manage significant loss of physical function and mobility [22].

Over the next 6 months, Márcia worked together with many different health-care providers in the hospital, rehabilitation center, and secondary prevention fracture clinic and achieved her goal of being back in the saddle within 1 year. 


\subsection{Nutrition Status and Physical, Functional, Exercise, and Rehabilitation Outcomes}

Malnutrition can influence physical and functional activity, exercise, and rehabilitation processes of older adults [23], increasing the length of stay in the hospital and the rates of readmission [24]. Nutritional status has been correlated with poor basic activities of daily living (ADL) and instrumental activities of daily living (IADL) in community-dwelling [22], institutionalized [25], and hospitalized older adults [26]. Older people who report unintentional weight loss are at a higher risk of developing limitations in ADL such as bathing, dressing, and eating [27], as well as older people who report obesity [28]. Also, low body mass index (BMI) [29] and high BMI [28] have been shown as a risk factor for the onset of activities of daily living limitations. Particularly the combination of a high BMI and dynapenia, defined as dynapenic obesity, is associated with a poorer physical function when compared to obesity alone [30]. Malnutrition has also been associated with high risk of falling [31], harmful falls [32], hip fracture incidence, and reduced ability to recover prefracture functional capacity in patients after hip fracture [33].

Vitamin D and protein has an important function on muscle strength, so its deficits can lead to muscle weakness [34]. Administration of high-protein diets, with protein throughout the three meals associated with high doses of calcium and vitamin D, can improve muscle health and decrease the risk of fracture [34] (Chap. 9).

\subsection{Combined Nutrition Physical Activity/ Exercise Interventions}

Consequently, we make the case that in the absence of adequate nutrition, physical activity or exercise interventions are unlikely to lead to optimized health or healthrelated quality of life for older adults like Márcia. Although the evidence remains inconsistent, there is a growing body of evidence to support combined nutrition and exercise/PA interventions in older adults. Particularly the combination of protein intake and nutrition counseling with exercise has demonstrated reduced long-term mobility disability [17, 22], improved frailty scores [35], improved lower limb functionality [35], and increased independence in activities of daily living [35].

\subsection{Physical Rehabilitation}

Rehabilitation is a set of person-centered interventions across multiple disciplines with the key objective of optimizing functioning and reducing disability [36]. A person-centered care approach for older people includes the assessment and development of a care plan based on the assessment of vitality (including the nutritional care), visual, hearing, cognitive, locomotor, and psychological capacities; underlying diseases (and risk factors); caregiving needs; assessment, selection, and 
provision of assistive products (e.g., walking aids, therapeutic shoes, grab bars); physical environment modifications; and need for social care (Chaps. 1 and 13) [37].

A comprehensive care approach conducted by an interdisciplinary team allows tailoring older people and caregiver's needs and ensures interventions orientated toward relevant outcomes, avoiding unnecessary treatments, polypharmacy, and poor adherence to interventions. Particularly for older people with significant loss of mobility due to chronic conditions, the combination of rehabilitation interventions and the enhancement of PA level may amplify positive outcomes [6].

\subsection{Enhancing Physical Activity Level Among Older People}

Diverse health-care professionals can help older people to increase their PA levels by exploring, discussing, and intervening to reduce barriers and enhance facilitators for being more active (Table 14.2) [38]. These actions include establishing and negotiating individual realistic goals, taking into account specific needs, health conditions, and physical limitations, and creating a shared, tailored plan that addresses each recommended type of activity/exercise with specific goals, need of supervision, and safety procedures. Applying behavioral strategies of positive reinforcement using motivational interviewing strategies to stimulate participation in PA demonstrates successful long-term results. Goal setting and self-monitoring in combination with the use of digital technologies such as sensors (e.g., pedometers and accelerometers) have also proven beneficial [38, 39]. The use of smartphone, tablet apps, and mobile text messages is promising and appears to be acceptable and beneficial for the maintenance and improvement of PA in the short term [39]. E-health strategies are being increasingly used to promote and track physical activity among older people (e.g., mobile apps, wearable, digital PA coaching, online social support, video demonstrations, video games, etc.) with positive results in increasing the time spent on physical activity, the energy expenditure in physical activity, and the number of walking steps. These strategies should be used to enhance physical activity level among older adults [39].

\subsection{Summary}

Benefits of physical activity are substantial and contribute to healthy aging. Particularly, multicomponent exercises, nutritional interventions, and rehabilitation can improve physical functioning and prevent disability. Health-care professionals play a key role in implementing strategies to enhance physical activity participation.

\section{Take-Home Points}

- The recommendation is 150-300 min of moderate-intensity aerobic physical activity or at least 75-150 min of vigorous-intensity aerobic physical activity or 
Table 14.2 Interdisciplinary opportunities for enhancing physical activity in older adults

\begin{tabular}{|c|c|c|}
\hline Who & What & How \\
\hline $\begin{array}{l}\text { Medical doctor/ } \\
\text { physician }\end{array}$ & Physical activity advice & $\begin{array}{l}\text { Specific physical activity advice (type, } \\
\text { frequency); plan of action and follow-up [40]; } \\
\text { address individual motivators, facilitators, and } \\
\text { barriers; refer to local physical activity } \\
\text { opportunities or to a professional able to offer a } \\
\text { specific physical activity or exercise plan }\end{array}$ \\
\hline Physiotherapist & $\begin{array}{l}\text { Promote physical } \\
\text { activity [41] and provide } \\
\text { tailored preventive } \\
\text { interventions and/or } \\
\text { rehabilitation program }\end{array}$ & $\begin{array}{l}\text { Assess and prescribe appropriate program } \\
\text { according to needs, preferences, abilities, and } \\
\text { conditions; specific physical activity advice } \\
\text { (type, frequency); plan of action and follow-up; } \\
\text { encourage progress and participation [42] }\end{array}$ \\
\hline $\begin{array}{l}\text { Physical educator } \\
\text { and fitness } \\
\text { professionals }\end{array}$ & $\begin{array}{l}\text { Provide tailored } \\
\text { physical activity/ } \\
\text { exercise program }\end{array}$ & $\begin{array}{l}\text { Assess and prescribe appropriate program } \\
\text { according to needs, preferences, abilities, and } \\
\text { conditions; specific physical activity advice } \\
\text { (type, frequency); plan of action and follow-up; } \\
\text { encourage progress and participation }\end{array}$ \\
\hline $\begin{array}{l}\text { Nurse and other } \\
\text { health-care } \\
\text { professionals }\end{array}$ & $\begin{array}{l}\text { Promote physical } \\
\text { activity participation }\end{array}$ & $\begin{array}{l}\text { Explore and discuss awareness of the benefits of } \\
\text { being active; address individual motivators, } \\
\text { facilitators, and barriers; refer to local physical } \\
\text { activity opportunities or to a professional able to } \\
\text { offer a specific physical activity or exercise plan } \\
\text { [43, 44] }\end{array}$ \\
\hline $\begin{array}{l}\text { Volunteers and } \\
\text { carers }\end{array}$ & $\begin{array}{l}\text { Promote physical } \\
\text { activity participation }\end{array}$ & $\begin{array}{l}\text { Be a physical activity enthusiast; explore and } \\
\text { discuss awareness of benefits of being active. } \\
\text { Address motivators, facilitators, and barriers; } \\
\text { refer to local physical activity opportunities or to } \\
\text { a professional able to offer a specific physical } \\
\text { activity or exercise plan [43]; provide support } \\
\text { and/or company to those who need it [38] }\end{array}$ \\
\hline Researchers & $\begin{array}{l}\text { Promote and } \\
\text { disseminate science }\end{array}$ & $\begin{array}{l}\text { Generate and implement high-quality evidence } \\
\text { for physical activity; investigate local barriers } \\
\text { and facilitators for implementing successful } \\
\text { strategies }\end{array}$ \\
\hline Policy makers & $\begin{array}{l}\text { Implement healthy } \\
\text { aging policies, } \\
\text { environments, and } \\
\text { infrastructure }\end{array}$ & $\begin{array}{l}\text { Provide free or low-cost exercise programs that } \\
\text { are tailored to personal needs and preferences } \\
\text { [4-6]; create safe environments, access to parks } \\
\text { and other recreational facilities, and safe } \\
\text { footpaths [45] }\end{array}$ \\
\hline
\end{tabular}

an equivalent combination of moderate- and vigorous-intensity activity throughout the week, for substantial health benefits.

- Older adults should combine aerobic, strengthening, and functional balance exercises.

- Exercise can be part of lots of things as recreation, work, or domestic activities.

- Doing some physical activity is better than doing none-it is important be physically active as their abilities and conditions allow.

- Nutritional treatment reduces the progression of functional decline, even further when associated with PA programs, reducing long-term mobility disability.

- The use of e-health strategies to enhance PA should be considered. 


\section{References}

1. Global strategy and action plan on ageing and health (2017). World Health Organization, Geneva. Contract no.: CC BY-NC-SA3.0IGO

2. American College of Sports M, Chodzko-Zajko WJ, Proctor DN, Fiatarone Singh MA, Minson CT, Nigg CR et al (2009) American College of Sports Medicine position stand. Exercise and physical activity for older adults. Med Sci Sports Exerc 41(7):1510-1530

3. Piggin J (2020) What is physical activity? A holistic definition for teachers. Res Policy Makers Front Sports Act Living 2:72

4. WHO (2019) Global action plan on physical activity 2018-2030: more active people for a healthier world. World Health Organization, Geneva

5. Tackling NCDs: 'best buys' and other recommended interventions for the prevention and control of noncommunicable diseases (2017). World Health Organization, Geneva

6. WHO (2020) WHO guidelines on physical activity and sedentary behaviour: at a glance. World Health Organization, Geneva. Report no.: 9240014888

7. Piercy KL, Troiano RP, Ballard RM, Carlson SA, Fulton JE, Galuska DA et al (2018) The physical activity guidelines for Americans. JAMA 320(19):2020-2028

8. Sparling PB, Howard BJ, Dunstan DW, Owen N (2015) Recommendations for physical activity in older adults. BMJ 350:h100

9. Duvivier BM, Schaper NC, Bremers MA, van Crombrugge G, Menheere PP, Kars M et al (2013) Minimal intensity physical activity (standing and walking) of longer duration improves insulin action and plasma lipids more than shorter periods of moderate to vigorous exercise (cycling) in sedentary subjects when energy expenditure is comparable. PLoS One 8(2):e55542

10. Hupin D, Roche F, Gremeaux V, Chatard JC, Oriol M, Gaspoz JM et al (2015) Even a lowdose of moderate-to-vigorous physical activity reduces mortality by $22 \%$ in adults aged $>/=60$ years: a systematic review and meta-analysis. Br J Sports Med 49(19):1262-1267

11. Cunningham C, Sullivan RO, Caserotti P, Tully MA (2020) Consequences of physical inactivity in older adults: a systematic review of reviews and meta-analyses. Scand J Med Sci Sports 30(5):816-827

12. Lee IM, Shiroma EJ, Lobelo F, Puska P, Blair SN, Katzmarzyk PT et al (2012) Effect of physical inactivity on major non-communicable diseases worldwide: an analysis of burden of disease and life expectancy. Lancet 380(9838):219-229

13. Blondell SJ, Hammersley-Mather R, Veerman JL (2014) Does physical activity prevent cognitive decline and dementia? A systematic review and meta-analysis of longitudinal studies. BMC Public Health 14:510

14. Guure CB, Ibrahim NA, Adam MB, Said SM (2017) Impact of physical activity on cognitive decline, dementia, and its subtypes: meta-analysis of prospective studies. Biomed Res Int 2017:9016924

15. Qu X, Zhang X, Zhai Z, Li H, Liu X, Li H et al (2014) Association between physical activity and risk of fracture. J Bone Miner Res 29(1):202-211

16. Oliveira JS, Pinheiro MB, Fairhall N, Walsh S, Chesterfield Franks T, Kwok W et al (2020) Evidence on physical activity and the prevention of frailty and sarcopenia among older people: a systematic review to inform the World Health Organization physical activity guidelines. J Phys Act Health 17(12):1247-1258

17. Integrated care for older people: guidelines on community-level interventions to manage declines in intrinsic capacity (2017). World Health Organization, Geneva

18. Paterson DH, Warburton DE (2010) Physical activity and functional limitations in older adults: a systematic review related to Canada's Physical Activity Guidelines. Int J Behav Nutr Phys Act 7:38

19. Mattle M, Chocano-Bedoya PO, Fischbacher M, Meyer U, Abderhalden LA, Lang W et al (2020) Association of dance-based mind-motor activities with falls and physical function among healthy older adults: a systematic review and meta-analysis. JAMA Netw Open 3(9):e2017688 
20. Sherrington C, Fairhall N, Kwok W, Wallbank G, Tiedemann A, Michaleff ZA et al (2020) Evidence on physical activity and falls prevention for people aged 65+ years: systematic review to inform the WHO guidelines on physical activity and sedentary behaviour. Int $\mathbf{J}$ Behav Nutr Phys Act 17(1):144

21. Sherrington C, Lord SR, Vogler CM, Close JC, Howard K, Dean CM et al (2014) A posthospital home exercise program improved mobility but increased falls in older people: a randomised controlled trial. PLoS One 9(9):e104412

22. Ferdous T, Cederholm T, Razzaque A, Wahlin A, Nahar KZ (2009) Nutritional status and selfreported and performance-based evaluation of physical function of elderly persons in rural Bangladesh. Scand J Public Health 37(5):518-524

23. Diekmann R, Wojzischke J (2018) The role of nutrition in geriatric rehabilitation. Curr Opin Clin Nutr Metab Care 21(1):14-18

24. Kruizenga H, van Keeken S, Weijs P, Bastiaanse L, Beijer S, Huisman-de Waal G et al (2016) Undernutrition screening survey in 564,063 patients: patients with a positive undernutrition screening score stay in hospital 1.4 d longer. Am J Clin Nutr 103(4):1026-1032

25. Suominen M, Muurinen S, Routasalo P, Soini H, Suur-Uski I, Peiponen A et al (2005) Malnutrition and associated factors among aged residents in all nursing homes in Helsinki. Eur J Clin Nutr 59(4):578-583

26. Oliveira MR, Fogaca KC, Leandro-Merhi VA (2009) Nutritional status and functional capacity of hospitalized elderly. Nutr J 8:54

27. Arnold AM, Newman AB, Cushman M, Ding J, Kritchevsky S (2010) Body weight dynamics and their association with physical function and mortality in older adults: the Cardiovascular Health Study. J Gerontol A Biol Sci Med Sci 65(1):63-70

28. Kong HH, Won CW, Kim W (2020) Effect of sarcopenic obesity on deterioration of physical function in the elderly. Arch Gerontol Geriatr 89:104065

29. Beydoun MA, Popkin BM (2005) The impact of socio-economic factors on functional status decline among community-dwelling older adults in China. Soc Sci Med 60(9):2045-2057

30. Bouchard DR, Janssen I (2010) Dynapenic-obesity and physical function in older adults. J Gerontol A Biol Sci Med Sci 65(1):71-77

31. Adly NN, Abd-El-Gawad WM, Abou-Hashem RM (2020) Relationship between malnutrition and different fall risk assessment tools in a geriatric in-patient unit. Aging Clin Exp Res 32(7):1279-1287

32. Lackoff AS, Hickling D, Collins PF, Stevenson KJ, Nowicki TA, Bell JJ (2020) The association of malnutrition with falls and harm from falls in hospital inpatients: findings from a 5-year observational study. J Clin Nurs 29(3-4):429-436

33. Malafarina V, Reginster JY, Cabrerizo S, Bruyere O, Kanis JA, Martinez JA et al (2018) Nutritional status and nutritional treatment are related to outcomes and mortality in older adults with hip fracture. Nutrients 10(5):555

34. Artaza-Artabe I, Saez-Lopez P, Sanchez-Hernandez N, Fernandez-Gutierrez N, Malafarina V (2016) The relationship between nutrition and frailty: effects of protein intake, nutritional supplementation, vitamin D and exercise on muscle metabolism in the elderly. A systematic review. Maturitas 93:89-99

35. Han CY, Miller M, Yaxley A, Baldwin C, Woodman R, Sharma Y (2020) Effectiveness of combined exercise and nutrition interventions in prefrail or frail older hospitalised patients: a systematic review and meta-analysis. BMJ Open 10(12):e040146

36. Stucki G, Bickenbach J, Gutenbrunner C, Melvin J (2018) Rehabilitation: the health strategy of the 21st century. J Rehabil Med 50(4):309-316

37. Integrated care for older people (ICOPE): guidance for person-centred assessment and pathways in primary care (2019). World Health Organization, Geneva

38. Perracini MR, Franco MRC, Ricci NA, Blake C (2017) Physical activity in older people-case studies of how to make change happen. Best Pract Res Clin Rheumatol 31(2):260-274

39. Kwan RYC, Salihu D, Lee PH, Tse M, Cheung DSK, Roopsawang I et al (2020) The effect of e-health interventions promoting physical activity in older people: a systematic review and meta-analysis. Eur Rev Aging Phys Act 17:7 
40. Hinrichs T, Brach M (2012) The general practitioner's role in promoting physical activity to older adults: a review based on program theory. Curr Aging Sci 5(1):41-50

41. Perracini MR, Freitas SMSF, Pires RS, Rico JMP, Alouche SR (2018) Promotion of physical activity for older people with neurological conditions. In: Nyman SR, Haines T, Musselwhite C, Victor CR (eds) The Palgrave handbook of ageing and physical activity promotion. Palgrave Macmillan, Basel, pp 145-163

42. Oliveira CB, Franco MR, Maher CG, Tiedemann A, Silva FG, Damato TM et al (2018) The efficacy of a multimodal physical activity intervention with supervised exercises, health coaching and an activity monitor on physical activity levels of patients with chronic, nonspecific low back pain (Physical Activity for Back Pain (PAyBACK) trial): study protocol for a randomised controlled trial. Trials 19(1):40

43. Palmer SJ (2020) Encouraging exercise in older adults: advice for nurses. Br J Community Nurs 25(2):95-97

44. Lee LL, Arthur A, Avis M (2008) Using self-efficacy theory to develop interventions that help older people overcome psychological barriers to physical activity: a discussion paper. Int J Nurs Stud 45(11):1690-1699

45. Peters M, Muellmann S, Christianson L, Stalling I, Bammann K, Drell C et al (2020) Measuring the association of objective and perceived neighborhood environment with physical activity in older adults: challenges and implications from a systematic review. Int J Health Geogr 19(1):47

\section{Recommended Reading}

Nyman SR, Barker A, Haines T, Horton K, Musselwhite C, Peeters G, Victor CR, Wolff JC (2018) The Palgrave handbook of ageing and physical activity promotion. Springer Nature, Basel

Perracini MR, Franco MRC, Ricci NA, Blake C (2017) Physical activity in older people-case studies of how to make change happen. Best Pract Res Clin Rheumatol 31(2):260-274

Sparling PB, Howard BJ, Dunstan DW, Owen N (2015) Recommendations for physical activity in older adults. BMJ. 350:h100

WHO guidelines on physical activity and sedentary behaviour: at a glance (2020). World Health Organization, Geneva

Open Access This chapter is licensed under the terms of the Creative Commons Attribution 4.0 International License (http://creativecommons.org/licenses/by/4.0/), which permits use, sharing, adaptation, distribution and reproduction in any medium or format, as long as you give appropriate credit to the original author(s) and the source, provide a link to the Creative Commons license and indicate if changes were made.

The images or other third party material in this chapter are included in the chapter's Creative Commons license, unless indicated otherwise in a credit line to the material. If material is not included in the chapter's Creative Commons license and your intended use is not permitted by statutory regulation or exceeds the permitted use, you will need to obtain permission directly from the copyright holder.

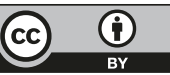

